\title{
Agnieszka Piela, Stownik frazeologizmów zarchaizmami. Pamiątki przeszłości, Wydawnictwo Naukowe PWN, Warszawa 2018, ss. 352
}

Słownik frazeologizmów z archaizmami. Pamiątki przeszłości to nowatorskie opracowanie naukowe, przynoszące wszechstronny i oparty na badaniach źródłowych (leksykograficznych i historycznojęzykowych) opis wybranych warstw zasobu frazeologicznego, a mianowicie frazeologizmów zawierających komponent archaiczny. Autorka słownika, Agnieszka Piela, należy do nielicznego grona badaczy zasobu frazeologicznego języka polskiego, którzy w swych pracach uwzględniają aspekt diachroniczny. Recenzowany słownik powstał jako uzupełnienie i rozszerzenie wcześniejszej monografii autorki: Pozorna tożsamość. Polskie tradycjonalizmy z semantycznym archaizmem (Katowice 2016) i wraz z tą publikacją wypełnia lukę w polskich badaniach frazeologii historycznej.

Za główny cel słownika badaczka obrała wskazanie licznych powiązań między dawną a współczesną polszczyzną przez wyodrębnienie we współczesnym języku polskim zbioru frazeologizmów i przysłów, które w swym składzie leksykalnym przechowują archaizmy, czyli stare słowa, ich formy i znaczenia. Materiał zgromadzony w opracowaniu dowodzi, że ślady historycznej polszczyzny obecne we współczesnym języku polskim są bardzo liczne, różnorodne i ciekawe. Autorka udokumentowała zbiór 500 haseł zabytkowych form języka, które są tworzywem leksykalnym ok. 800 frazeologizmów i przysłów.

Przedmiotem opisu w słowniku są utrwalone związki wyrazowe, które w swym składzie mieszczą komponent będący ,pamiątką po wcześniejszych etapach rozwojowych polszczyzny, $\mathrm{tj}$. $\mathrm{z}$ archaizmami, anachronizmami i historyzmami” (s. 9). Archaizmem autorka nazywa „każde stare zjawisko językowe, stanowiące w dzisiejszym języku pozostałości (pamiątki) po dawnych etapach 
rozwojowych polszczyzny" (s. 11). Zgodnie z przyjętymi założeniami w słowniku zarejestrowano utrwalone połączenia wyrazowe, przysłowia i zestawienia terminologiczne, które zawierają komponent archaiczny: relikt fonetyczny, fleksyjny, słowotwórczy, leksykalny bądź semantyczny. Nie uwzględniono natomiast połączeń wyrazowych nazywających dawne realia (np. czytać od deski do deski, pleść jak Piekarski na mękach, wyjść na czym jak Zabłocki na mydle).

Artykuły hasłowe w słowniku zbudowane są konsekwentnie i według następującego schematu. Wyrazem hasłowym każdorazowo jest zabytkowa forma językowa, najczęściej pojedynczy wyraz (np. bakcyl, myto, mores, napłatać, nadobny, nawiąza, nieboga, nice, nierychliwy, niewczas, obuch, odczepne, ogródka, omacek, opak, oślep, opierunek, ościén, panewka, pardon, parol) lub w przypadku archaizmów fleksyjnych - wyraz podstawowy z historyczną formą fleksyjną (np. deszcz - dżdzu; ki-kiego; kraj-kraja; lata-laty, leciech; si-siego, sio; stowo - stowy, stowie; wilk-wilcy). W nazwach hasel uwzględnia się również warianty fonetyczno-ortograficzne różnych leksemów (np. oścież // roścież // rozcież; tynf // tymf). W przypadku haseł o obcej proweniencji (np. czambut, kabza, kaduk, kamasz, kalendy, karb, kares) podawane są w nawiasie informacje o języku, z którego się wywodzą.

Na podkreślenie zasługuje fakt, że każdy wyraz hasłowy opatrzony jest kwalifikatorem chronologicznym; stosuje się trzy rodzaje kwalifikacji, określając historyczne przeżytki językowe mianem: archaiczny, przestarzały lub historyzm. Wśród form archaicznych wyróżnia się archaizmy fonetyczne (np. przyszła na kogoś kryska; Przyszła kryska na Matyska // Matyska); archaizmy fleksyjne (np. we dnie i w nocy; Jeden do Sasa, drugi do lasa; siedzieć z założonymi rękoma); archaizmy słowotwórcze (np. zadać komu kłam; coś woła o pomstę do nieba; Złej tanecznicy zawadza (przeszkadza) i rąbek u spódnicy); archaizmy leksykalne (np. bez liku; nudy na pudy; po omacku); archaizmy semantyczne (np. Kto zjada ostatki, ten (jest) piękny i gładki; słomiany wdowiec); archaizmy składniowe (np. paść trupem; zapomnieć na śmierć). Do wyrazów, kwalifikowanych jako przestarzałe, nazywanych też anachronizmami, w słowniku zalicza się leksemy wychodzące z użycia, obecne jedynie w słownictwie najstarszego pokolenia Polaków (np. awanse, baczność, cenzurka, gżegżótka). Z kolei mianem historyzmów Piela określa archaizmy rzeczowe, czyli nieużywane współcześnie wyrazy nazywające realia minionych czasów (np. basalyk, ceber, garniec, korzec, kluba, piędź, pręgierz).

Wyrazy hasłowe, będące historycznymi komponentami frazeologizmów, zdefiniowane zostały na podstawie współczesnych słowników języka polskiego, a także z wykorzystaniem źródeł historycznych, słowników etymolo- 
gicznych, gwarowych, paremiologicznych i wydawnictw encyklopedycznych. Każdy związek wyrazowy został w słowniku opatrzony cytatem ilustrującym jego użycie. Cytaty pochodzą w większości z utworów dawnej i nowej literatury polskiej, z tekstów prasowych, ze źródeł internetowych, a zaczerpnięte zostały z dostępnych w Internecie korpusów języka polskiego. Dobór cytatów z różnorodnych źródeł udowadnia, że zarejestrowane w słowniku frazeologizmy są wciąż żywe w mowie współczesnych Polaków.

Wiele artykułów hasłowych zostało wzbogaconych o dodatkowe informacje o charakterze ciekawostek językowych, które zostały wyodrębnione graficznie i ujęte w ramki, np. przy hasłach: arbuz, baka, chrapka, ćwik, drapak, duch, dunder, fryga, kamasz, koperczaki, kryska. Zawarte w nich są komentarze historycznojęzykowe na temat ewolucji formalno-znaczeniowej poszczególnych reliktów lub związków wyrazowych, informacje kulturowe dotyczące dawnych realiów społecznych, zwyczajów i desygnatów, które wyszły z użycia. W ramkach znajdują się również wskazówki faktograficzno-etymologiczne i odesłania do bibliografii zamieszczonej w końcowej części słownika.

Na uwagę zasługuje spójna, przemyślana makrostruktura słownika. Po części wstępnej, zawierającej swoistego rodzaju kompendium wiedzy na temat frazeologizmów z komponentem archaicznym, następuje konsekwentnie opracowana część zasadnicza, czyli artykuły hasłowe, graficznie i typograficznie wyodrębnione, ułożone w porządku alfabetycznym. Oprócz wykazów stosowanych skrótów i bogatej bibliografii słownik zawiera również alfabetyczny indeks reliktów językowych wraz z zarejestrowanymi przy nich związkami wyrazowymi.

Przegląd materiału zgromadzonego w słowniku skłania do postawienia pytania o to, od czego zależy utrata żywotności przez poszczególne wyrazy. Autorka, próbując rozwiązać tę kwestię, zauważa, że jedną z właściwości frazeologii jest jej konserwatyzm, skłonność do utrwalania i przechowywania wszelkich staroci językowych, które w ustabilizowanych, skostniałych konstrukcjach językowych są mniej podatne na przeobrażenia niż pojedyncze leksemy. Frazeologizmy oprócz charakterystycznej formy wyróżniają się spośród innych konstrukcji wielowyrazowych globalnością znaczenia, i właśnie ta cecha chroni je przed zapomnieniem.

Charakter materiału frazeologicznego zgromadzonego w słowniku pozwala widzieć w nim dzieło chroniące ślady historyczno-kulturowego dziedzictwa językowego, z którego obecności w naszym języku większość użytkowników polszczyzny nie zdaje sobie sprawy. Ze względu na bogactwo przydatnych informacji, które przynosi ten interesujący słownik, można go polecić różnym grupom odbiorców. Badacze frazeologii znajdą w nim wzór rozwiązywania 
kwestii etymologicznych, uczniowie, studenci i tłumacze skorzystają zapewne z powiązania frazeologii z kontekstem kulturowym. Słownik ten adresowany jest również do szerokiego grona czytelników ceniących wiedzę humanistyczną, zainteresowanych relacjami między językiem a historią i kulturą. Dla miłośników języka polskiego opracowanie Pieli jest nieocenioną skarbnicą ciekawostek językowych; współczesnym użytkownikom polszczyzny unaocznia, że często nie są świadomi funkcjonowania w ich codziennej mowie wielu połączeń wyrazowych, będących zabytkowymi formami językowymi (np. blady jak chusta; błędne koło; wziąć kogoś, coś na cel; człowiek starej daty; we dnie i w nocy; eliksir młodości; pod czyimś kierunkiem; mieć na co chrapkę; nie w kij dmuchat; nudny jak flaki z olejem; odwaga cywilna; szyty grubymi nićmi; zasięgnać języka). Słownik Agnieszki Pieli uznać należy za dzieło bardzo wartościowe pod względem poznawczym, które poszerza naszą wiedzę o ważnych kulturowo, a dotychczas mało zbadanych częściach polskiego zasobu językowego.

Gabriela Dziamska-Lenart 